EESTI RAKENDUSLINGVISTIKA ÜHINGU AASTARAAMAT 1 (2004), 19-34

\title{
IMITATIIVIDE KOHAST LASTEKEELES: \\ REDUPLIKATSIOONIST, MORFOLOOGIAST JA SÕNALIIGILISEST AMBIVALENTSUSEST
}

\author{
REILI ARGUS
}

Ülevaade. Artiklis on vaatluse all selgelt eristuva leksikaalse kihi, imitatiivide omandamine. Keelematerjaliks on ühe eesti keelt emakeelena omandava lapse spontaanse kõne lindistused. Lisaks lapse kõnele on vaadeldud ka lapse vestluspartneri, ema keelekasutust. Analüüsitud materjali põhjal võib väita, et varased onomatopoeetilised sõnad, sh eelkõige imitatiivid on sõnaliigilt ambivalentsed, lapse keeles varased, lapse ja vanema keeles sagedased, varasel perioodil enamasti reduplikatiivsed, imitatiividele omase reeglipäraselt varieeruva häälikulise kujuga ning sõltuvad teatud määral sotsiokultuurilisest keelekeskkonnast. Lapse vanemaks saades muutuvad kõnealused sõnad nii lapse kui ka vanema keelekasutuses morfoloogiliselt keerukamaks, samuti jääb vestlustes vähemaks onomatopoeetilisi sõnu sisaldavaid rutiinsituatsioone. Eelöeldu annab alust oletada, et onomatopoeetiliste sõnade ja imitatiivide sagedase kasutamise üldisem eesmärk on suhtlusprotsessi lihtsustamine, tugiverbikonstruktsioonide ja hilisem sama leksikaalse sisuga tuletatud verbide esinemine demonstreerib ka morfoloogilise keerukuse vältimist. ${ }^{1}$

Võtmesõnad: keeleomandamine, lapsekeel, onomatopoeetilised sõnad, imitatiivid, reduplikatsioon, pre- ja protomorfoloogia, hoidjakeel, eesti keel

Eesti keele ikoonilist sõnavara, sh onomatopoeetilisi sõnu, on käsitletud eelkõige tõlkeproblemaatikaga seoses (vt nt Hausenberg 1979, Mikone 2002, Veldi 1997, Jürvetson 2003), nende omandamine ei ole aga ühegi senise käsitluse keskpunktis olnud. Onomatopoeetilised ehk helijäljenduslikud sõnad moodustavad selgelt eristuva sõnavarakihi, eripärase fonosemantilise allsüsteemi (Veldi 1999: 211), tegemist on paljudele keeltele omase universaaliga, mille olulisus ilmneb eriti selgelt just keele omanda-

$5 \quad$ Artikkel valmis tänu Alfred Kordelini SA Eesti fondile. 
mise kontekstis ning mida on alljärgnevalt vaadeldud, asetades tähelepanu keskmesse eelkõige grammatika, mitte foneetika ega leksika omandamise².

Võtmeterminit onomatopoeetiline sõna on defineeritud eri kirjutistes eri täpsusastmega, termini ebajärjekindlale kasutamisele on juhtinud tähelepanu Eve Mikone (Mikone 2002: 30). Siinkirjutaja lähtub küll Enn Veldi pakutud mõisteseletusest, mille järgi "termin onomatopoeetiline sõna tähistab ikoonilist sõna, mille referendiks on mingi akustiline nähtus" (Veldi 1997: 236), kuid eristab onomatopoeetiliste sõnade hulgas veel imitatiive. Imitatiiviks on loetud onomatopoeetiline sõna, mille häälikuline kuju võib olla varieeruv, mis ei muutu aga morfoloogiliselt, ei kuulu mitte alati leksikoni püsiossa (vastupidiselt onomatopoeetilistele sõnadele üldiselt), vaid võib olla ka spontaanselt moodustatud leksikaalne üksus, mille keskseks omaduseks on helijäljenduslikkus. Näiteks oleks tüüpiliseks imitatiiviks reduplikatiivne kiirabiauto signaali imiteeriv iiuiiu, mittetüüpiliseks kõndimise kohta kasutatav tip-tap või tap-tap, mille tähenduskomponentide hulgas on peale heli olulisel kohal ka liikumise laad ehk deskriptiivne tähenduskomponent. Eelöeldu demonstreerib mingil määral ka onomatopoeetilise sõna imitatiiviks määramise problemaatilisust, sageli ei ole piir tavalise onomatopoeetilise sõna ja imitatiivi vahel (nii nagu sageli ka deskriptiivse ja onomatopoeetilise sõna vahel) väga selgelt määratletav. Termin imitatiiv on ekspressiivse sõnavara kirjeldamisel kasutusel ka soomekeelses erialakirjanduses (Leskinen 2001: 40).

Onomatopoeetilistele sõnadele on omane traditsiooniliste grammatiliste paradigmade puudumine (Wescott 1980: 22). Lastekeelealastes uurimustes on onomatopoeetilised sõnad (koos hüüd- ja reduplikatiivsete sõnadega) arvatud grammmatikaväliste ${ }^{3}$ leksikaalsete üksuste hulka (Dressler jt 2002: 406). Eelnimetatud leksikaalsete üksustega on kokku puutunud pea kõik laste varase sõnavara uurijad, kuid sageli tundub, et neist on üritatud üle vaadata, hoolimata sealjuures tõsiasjast, et onomatopoeetilised sõnad moodustavad varase sõnavara hulgas märkimisväärse

2 Uurimiseesmärgist tulenevalt ei ole näidete esitamisel kasutatud foneetilist transkriptsiooni, näited on vastava vanuse keelematerjali käsitlenud autorite eeskujul (vt nt Protassova 1997 või Voeikova 1997) pandud kirja kuuldeortograafiat järgides, kasutades lastekeele materjali analüüsimiseks mõeldud tarkvaralahendust CLAN.

3 Kasutades terminit "grammatikaväline", tuleks siinkohal mainida, et mõnes keeles on reduplikatsioon siiski selgelt grammatiline vahend, nt hiina keeles kasutatakse reduplikatsiooni määrsõnade moodustamiseks ja hulga väljendamiseks (Keelteatlas 2000: 22). 
hulga. Nn tülika keelematerjaliga tegelemist raskendab ühe tegurina eelmainitud leksikaalsete üksuste ähmane sõnaliigiline kuuluvus. Liigitusprobleem tuleneb omakorda just andmetöötlusega seotud üheste lahenduste vajalikkusest, nõuab näiteks tekstikorpuse märgendamine iga sõna sõnaliigilise kuuluvuse konkreetset määramist.

Varase sõnavara ja onomatopoeetiliste sõnade analüüsi juurde asumisel on alljärgnevalt tuginetud eelkõige konstruktivistlikule seisukohale, mille järgi grammatika omandamine ei toetu kaasasündinud grammatilistele (või morfoloogilistele) parameetritele ning on väga oluliselt mõjutatud hoidjakeelest (konstruktivistliku käsitluse põhiseisukohtade kohta vt nt Dressler jt 2002 või Bittner jt 2003) ning grammatika omandamist võib vaadelda kui õppimisprotsessi, mis juhindub muude tegurite kõrval eelkõige teatud keelenähtuste või struktuuride esilduvusest, sagedusest hoidjakeeles ja loomulikkusest. Konstruktivistlike seisukohtadega haakub ka sotsiopragmaatiline keeleomandamiskäsitlus, mille järgi omandavad lapsed keelelisi sümboleid kui üht osa sotsiaalsest terviksuhtlusest, keelt omandatakse kui üht sotsiokultuurilist konventsiooni (Tomasello 2000: 135). Nii on omandamise seisukohast äärmiselt olulised kindlad rutiinsõnad, nt tervitused, tänamine, ning kindlate igapäevaste situatsioonide juurde kuuluvad väljendid, nn suhtlusrutiinid, sh ka laulud ja mängud. Mõlemat teoreetilist lähenemist iseloomustab huvi hoidjakeele vastu.

Eelnimetatud teoreetiliste käsitluste põhjal võib eeldada, et:

1) onomatopoeetilised sõnad, sh imitatiivid, kuuluvad lapse esimeste sõnade hulka ning on varased seetõttu, et nad on hoidjakeeles sagedased, sotsiokultuuriliste rutiinsituatsioonide osad;

2) varased, premorfoloogilise perioodi onomatopoeetilised sõnad, eriti just imitatiivid, on oma sõnaliigilisuselt ambivalentsed;

3) onomatopoeetiliste sõnade, sh imitatiivide arv väheneb üldise sõnavara kasvades ning onomatopoeetiliste sõnade arv väheneb lapse vanemaks saades ka hoidjakeeles.

Keelematerjali põhiosa moodustab koostamisjärgus olev CHILDES-i alamkorpus Mia (lindistatud dialoogid vanusest $0 ; 11-1 ; 6$, koostanud Liina Vagula ja Reili Argus), võrdluseks on esitatud näiteid ka CHILDES-i eesti keele alamkorpusest Hendrik (lindistatud dialoogid vanusest 1;7-2;5, koostanud Reili Argus), millega täielik võrdlus ei ole lindistusperioodide erinevuse tõttu võimalik. 


\section{Imitatiivid on esimesed}

Onomatopoeetilised sõnad kuuluvad laste varase sõnavara hulka, ilmuvad lalisemisperioodi lõpul, mil suur osa kõnest on veel arusaamatưt. Päris esimesed onomatopoeetilised sõnad on registreeritud juba enne lapse aastaseks saamist: Mial näm (vanuses 0;10.12), mää ja mõmm (vanuses 1;0.25), njäu (vanuses 1;1.4) ning Hendrikul auh-auh 'koer', $k r r$ 'vares', $d r r$ 'auto, ka muud põrisevad masinad' (vanuses 1;0.12). Ilmselgelt on eelnimetatud sõnad saanud tuge hoidjakeelest, esimestes lindistustes esinesid ema kõnes onomatopoeetilised sõnad enamasti mitmete nn sotsiokultuuriliste rutiinsituatsioonide osana, sageli mingis mängus või laulukatkes:

(1) EMA: kuidas kutsu teeb, Mia? kommentaar: Mia naerab.

(2) EMA: mõmm, mõmm, mõmm, mõmm, kes see laulab mõmm, mõmm?

Mõned eelesitatud näited, nagu $k r r$ varese kohta ja $d r r$ auto kohta, on aga selgelt spontaanselt moodustatud ehk imitatiivid.

\section{Imitatiivid on sageli reduplikatiivsed ning kõnest hõlpsasti segmenteeritavad}

Üht keelelise arengu olulist etappi märgib lapse oskus eristada täiskasvanute kõnejadast sõnapikkuseid leksikaalseid üksuseid (Laalo 1997: 186). Onomatopoeetilised sõnad, eriti imitatiivid, tõusevad täiskasvanute kõnes oma prosoodiliste omaduste poolest selgemini esile ning on sageli reduplikatiivsed. Reduplikatsioon on ühelt poolt tihedalt seotud hoidjakeelele omaste sotsiokultuuriliste rutiinsituatsioonidega (kiigutamine, kussutamine, hüpitamine jms), teisalt, omandamise seisukohalt segmenteeritavuse ja sealtläbi esilduvusega. Hoidjakeeles esinevad reduplikatiivsed sõnad annavad lapsele juhiseid selle kohta, kus asub sõna piir, kui pikk on mingi keeleline üksus.

Vaadeldud materjalis leidus nii lapse kui ka vanema kõnes peaaegu igast onomatopoeetilisest sõnast ka reduplikatiivne variant, vanem kasu-

\footnotetext{
Siinkohal tasub põgusalt peatuda ka varase häälitsuse sõnaks määramise kriteeriumitel. Kirjutises on lähtutud Marilyn Vihmani esitatud määrangust: sõnaks on loetud lapse häälitsus, mis sarnaneb täiskasvanu vastava sõnaga ning millel on stabiilne kontekstuaalne kasutus (Vihman, McCune 1994: 518).
} 
tas tugiverbi ja imitatiivi konstruktsioone (tugiverbi mõiste kohta vt Muischnek 2004: 579), nagu teeb kop-kop, teeb tuut-tuut (mitte tuututab, koputab). Mainitud konstruktsioonide puhul on olulised kaks aspekti: segmenteeritavus ja morfoloogilise süsteemi omandamine. Nimelt annab vanem lapsele ette justkui ilma morfoloogiata "keeletüki", imitatiivi, mida saab kasutada nii, et sellele ei pea lisama ei pöördelõppe, tuletusliiteid ega muud morfoloogilist informatsiooni, mis ei muutu seega pikemaks kui kaks silpi ning millega koos käib sage, grammatilist informatsiooni kandev, lihtne ja vara omandatud tuumverb tegema. Laps omakorda jätab tuumverbi, mis leksikaalset informatsiooni ei anna, ütlemata ja kasutab ainult reduplikatiivset imitatiivi (vt näide 6). Tegema-verbi ärajätmine ja pelgalt imitatiivi kasutamine verbi funktsioonis tundub olema eesti keele omandamise varasele etapile omane, nähtusele on juhtinud tähelepanu ka Tiiu Salasoo (2003: 154).

Reduplikatsiooni kasutatakse just perioodil, mil lapse kõnes esineb lalisemisperioodile iseloomulikke silbijadasid ning grammatika omandamine pole veel alanud. On isegi väidetud, et lapse varane kõne on valdavalt reduplikatiivne (Savinainen-Makkonen 1998: 49) ning et reduplikatsiooni kasutamine taandub täiskasvanupärasele grammatikale üleminekul (Protassova 1997: 157, Voeikova 1997: 37, Savinainen-Makkonen 1998: 49). Materjali hoidjakeele osas domineerisid reduplikatiivseid imitatiive sisaldavad tugiverbikonstruktsioonid lapse vanuseni 1;3.22.

\section{Imitatiivide kuju ei ole stabiilne}

Onomatopoeetiliste sõnade puhul kasutatakse samade helide edastamiseks keeliti sarnaseid, kuid ometi mitte identseid struktuure, sõnad on alati küll reaalse heli sarnased, mitte absoluutsed koopiad (Veldi 1997: 226). Onomatopoeetiliste sõnade, eriti imitatiivide kuju varieerub aga ka ühe kasutaja, nii lapse kui ka ema kõnes (vt ka Salasoo 2003: 155), ühest lekseemist esines materjalis enamasti vähemalt kaks häälikuliselt sarnast, kuid siiski mõnevõrra erinevat varianti ning leidus ka lekseeme, millest oli kirja pandud isegi kuni kuus varianti ${ }^{5}$ : nt eristati Mia ema kõnes ühe

5 Tuleb lisada, et variantide rohkus sõltub paljuski litereerija töö täpsusest, nt nõrgatugeva klusiili eristamine vajaks aga nii kvaliteetsemat lindistusaparatuuri kui ka litereerimistehnikat. 
lekseemi eri häälduskujudena mjäu, njäu, mjau, njau, njää, mjää. Häälikulise kuju varieerumine ongi onomatopoeetilistele sõnadele üldiselt omane (Wescott 1980: 22) ning oli vaatlusaluseski materjalis selgelt süsteemipärane. Imitatiivide hulgas võis analüüsitud materjalis registreerida kolme liiki häälikuvaheldusi. Kui konsonantidest vaheldus ainult sõnaalguline nasaal: mjäu - njäu, siis vokaalide vaheldumine, mis arvatakse olevat onomatopoeetilistele sõnadele iseloomulikumgi (Veldi 1997: 227), oli märksa üldisem. Kõige sagedamini vaheldus sõnasisene madal vokaal kõrge vokaaliga: mjau - mjäu, njau - njäu, tap-tap - tip-tip. Madala ja kõrge vokaali vaheldumisel on oluline roll häälikusümboolikal, võib oletada, et $i$-häälik, mis sageli märgib deminutiivsust (Wescott 1980: 9), viitab eeltoodud näidetes kas vaiksemale, kuid kõrgemale helile või väiksematele sammudele kui $a$-häälikuga väljendatud sõnakuju. Reeglipäraseks võib pidada ka pika vokaali vaheldumist diftongiga: njää - njäu, mjää - mjäu, kus diftongiseerunud variant tähistab lühemat ja mõnevõrra nõrgemat heli kui pika vokaaliga variant (vt ka Veldi 1997: 228). Seega nähtub, et häälikusümboolikaga seotud häälikute varieerumist esineb lapse keelekasutuses tunduvalt varem kui näiteks vormimoodustusega seotud tüve allomorfide vaheldumist (vt nt Argus 2004: 40).

\section{Imitatiivid on sagedased nii laste- kui ka hoidjakeeles}

Alljärgnev diagramm 1 annab ülevaate onomatopoeetiliste sõnade kasvust Mia kogu sõnavara kasvu taustal. Tuleb aga kohe lisada, et vanuses 1;5.20 hüppeliselt kasvanud sõnavara võib tuleneda kahest asjaolust: ühelt poolt ongi tõenäoline, et selles vanuses toimus nn sõnavarahüpe (vt nt Bloom 2001: 39), teisalt muutus aga ka lindistussituatsioon, nimelt lindistas mainitud vanusest alates lapse kõnet tema enda ema, see aga tingis tunduvalt vabama suhtluse ja suurema sõnavara.

Lapse varase sõnavara hulgas on onomatopoeetilisi sõnu rohkesti (vt diagramm 1), nende kasutus väheneb aga sedamööda, kuidas sõnavara kasvab. Vanuses 1;5.20, mil sõnavara on kasvanud 75-lt 235-le sõnale, on onomatopoeetiliste sõnade arv vähenenud 16-lt 8-le.

Rutiinväljendite, sh onomatopoeetiliste sõnade kasutamine on suuresti ebateadlik, olgugi et tegemist on kõnes sagedaste üksustega, jäävad nad 
Diagramm 1. Onomatopoeetiliste sõnade hulk

Mia kõnes vanuses $0 ; 11-1 ; 6.4$

Mia

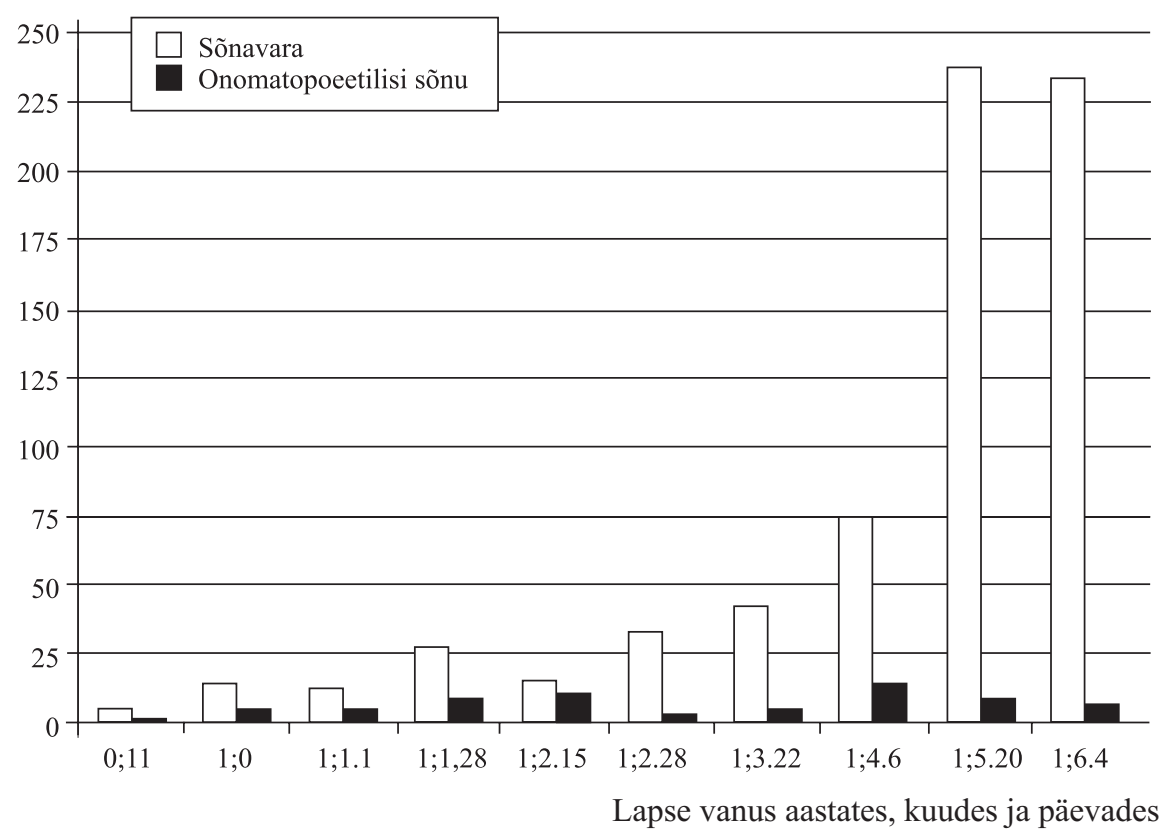

ladusas suhtluses enamasti märkamata (vt ka Coulmas 1979: 257). Vaatlusalusegi lapse ema ei arvanud end sedalaadi sõnu kuigi palju kasutavat, ometi moodustasid need lapse varase keele arengu etapil ema kogu lapsega kasutatavast sõnavarast märkimisväärse osa (vt diagramm 2). Florian Coulmasi (1979: 251) väitel on rutiinväljendite esmaseks funktsiooniks muuta suhtlusprotsess lihtsamaks, lihtsustamine on aga hoidjakeele kasutamise esmane eesmärk.

Tiiu Salasoo (2003: 154) väidab ükskeelse ja kakskeelse lapse keeleomandamise võrdlemisel, et ükskeelsel lapsel esines onomatopoeetilisi ja hoidjakeelseid sõnu märksa rohkem kui kakskeelsel lapsel, kelle eesti keelt mitte esimese keelena kõneleva ema sõnavaras sedalaadi sõnad puudusid. Seega võib oletada, et igale sotsiokultuurilisele keeleruumile on omased mingid kindlad onomatopoeetilised rutiinsõnad, mis on, nagu siinsestki materjalist ilmneb, sageli seotud kas mõne laulu või mänguga. Soome keele onomatopoeetiliste sõnadega seoses on sageli mainitud laulu "ihhahaa ihhahaa, hepo hirnahtaa" (Laalo 1997: 190, Savinainen- 
Diagramm 2. Onomatopoeetiliste sõnade hulk hoidjakeeles

Mia ema Ingrid

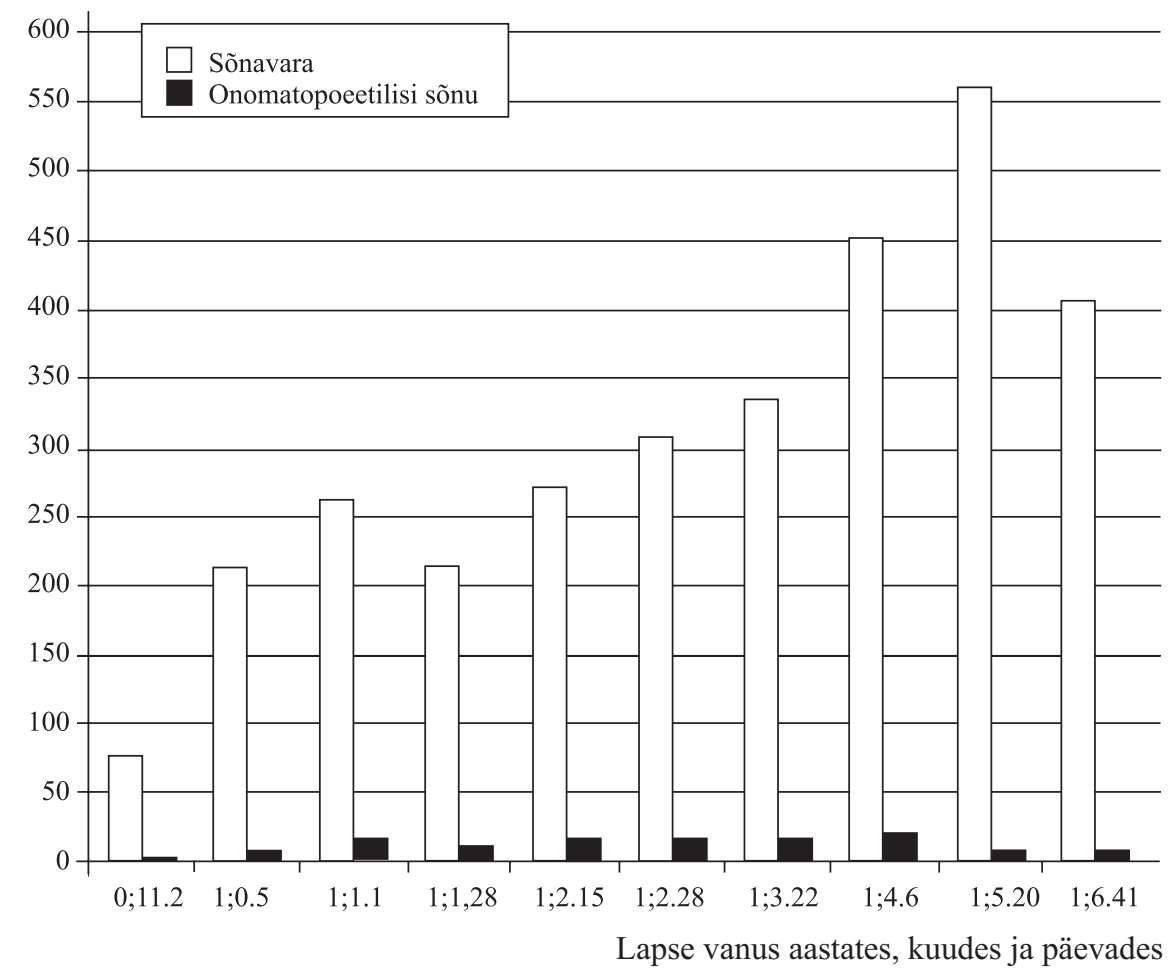

Makkonen 2001: 75). Eesti keeleruumis annavad sedalaadi rutiinsituatsioonide eksisteerimisest märku näiteks mõlema lapse kõnematerjalis esinenud onomatopoeetilisi sõnu sisaldavad laulukatked "mull-mull-mullmull väiksed kalad ..", "mõmm-mõmm laulab karujõmm ..” või sõna "kuku!" abil peitusemäng ja loomade piltide vaatamisel loomahäälte tegemine. Esimestes lindistatud dialoogides torkas silma, et eelmainitud rutiinsituatsioonid ning -väljendid moodustavad suure osa vanemate ja väikese lapse igapäevasuhtlusest. Lapse kasvades nende hulk väheneb ja sedakaudu jääb vähemaks ka onomatopoeetilisi sõnu.

Onomatopoeetiliste sõnade hulk hoidjakeeles ei ole kogu vaatlusperioodi lõikes stabiilne, see hakkab vähenema aktiivse morfoloogia omandamise alguses, lapse vanuses 1;5.20. Tegemist on vanusega, mil lapse kõnest on registreeritud hulk morfoloogilisi markereid, nt 1. ja 2. pöörde lõpud, lihtmineviku tunnus ja genitiivi tüved, ning mida võib pidada 
siirdumiseks premorfoloogiliselt perioodilt protomorfoloogilisse ehk morfoloogilise süsteemi loomise perioodi (pre- ja protomorfoloogilise perioodi kohta vt Argus 2004: 23).

Nn grammatikaväliseid konstruktsioone, sh reduplikatiive ning onomatopoeetilisi sõnu on peetud iseloomulikuks just eelgrammatilisele perioodile (Protassova 1997: 154). Väidetavalt väheneb onomatopoeetiliste sõnade üldine hulk pidevalt juba enne protomorfoloogilise perioodi algust (Dressler jt 2002: 406) ning protomorfoloogilisel perioodil, mil laps alustab morfoloogia loomist, need lapse keelekasutusest peaaegu et kaovad (Dressler, Kilani-Schoch 2002: 95). Diagrammidel 1 ja 2 esitatud andmete põhjal võib väita, et eelesitatud väide kehtib nii lapse- kui ka hoidjakeele onomatopoeetiliste sõnade, aga eriti imitatiivide kohta. Protomorfoloogilisel perioodil leidub sõnavara hulgas küll konventsionaalseid onomatopoeetilisi sõnu, mis saavad edaspidigi tuge hoidjakeelest ning jäävad lapse keelekasutusse püsima, imitatiivid aga kaovad nii lapse kui ka vanema kõnest.

\section{Imitatiivid on premorfoloogilisel perioodil sõnaliigilt ambivalentsed}

Lapse varaste sõnade sõnaliigilise kuuluvuse probleem tekib enamasti siis, kui on eesmärgiks kirjeldada sõnavara arengut sõnaliigiti. Sageli on lihtsalt väidetud, et presüntaktilise perioodi sõnade liigitamine sõnaliikidesse ongi problemaatiline (vt nt Griffiths 1992: 294, Salasoo 2003: 156) või et sõnaliikidest saab rääkida alles mitmesõnaliste väljendite kasutamisest alates (Clark 1993: 38).

Järgnevatest kõnelõikudest esimene, näide 3, on lindistatud lalisemisperioodi lõpus, mil lapse kõnes esines küll üksikuid sõnu, kuid lalina hulk kogu kõnes oli veel märkimisväärne ning tähenduslike üksuste häälikuline kuju ebastabiilne. Nii näites 3 kui ka 4 jääb selgusetuks, kas laps mõtleb imitatiiviga tegevust või objekti, mis vastavat häält teeb:

(3) (Mia vanuses 1;0)

EMA: kas lähme õue, kuule?

MIA: äh äh äh.

EMA: uu?

kommentaar: ema üritab võita lapse tähelepanu

MIA: addrr, drrr, brrr.

EMA: just, niimoodi sa õues sõidad vankriga. 
(4) (Hendrik vanuses 1;9)

EMA: ma joonistan auto.

EMA: tuleb.

kommentaar: osutab autole paberil

EMA: nii, tuled teen.

EMA: sina tee katusele.

HEN: iiuiiu [= kas vilkurid - nimisõnana või teevad iiuiiu - verbina] kommentaar: Hendrik joonistab vilkureid.

Eesti keeles on leksikaalse üksuse sõnaliigilise kuuluvuse määramisel aluseks kolme tasandi, morfoloogia, süntaksi ja semantika tunnused. Et lastekeeleuurijal tekivad liigitusprobleemid eelkõige lapse varase keelematerjali sõnaliigilisel märgendamisel, selgub enamasti, et eelnimetatud kriteeriumitest polegi palju abi: esiteks ei ole ei lapse sõnadel muutetunnuseid (seega ei saa arvestada morfoloogilisi tunnuseid) ega sageli ka lauset kui konteksti (puuduvad süntaktilised tunnused). Varaste imitatiivide liigitamisel sõnaklassidesse võiks siiski abi olla laiemast kontekstist (ka konsituatsioonist):

(5) (Hendrik vanuses 1;7)

EMA: mis sa?

kommentaar: Hendrik podiseb

EMA: pota pota, mis sa tahad?

HEN: trra.

EMA: prra?

kommentaar: ema joonistab auto

EMA: no nii, ratta joonistan ja.

Ning hiljem, kahesõnaliste väljendite perioodil saab aga lähtuda juba vastava sõna positsioonist lausungis ehk süntaktilisest opositsioonist:

(6) (Hendrik vanuses 1;11)

kommentaar: ema näitab legomehikest

HEN: onu.

EMA: see on ka onu.

HEN: mõmmi taptap.

kommentaar: paneb mõmmi kõndima

EMA: taptap teeb?

Samas leidub lapse kõnes hulk näiteid, kus ka konteksti toel jääb sõnaliigilisus ikkagi ähmaseks ja positsioonist on üldse veel vara rääkida, sest lapse väljendused ei ole pikemad kui üks sõna.

Jälgides onomatopoeetiliste sõnade kasutust hoidjakeeles, võib täheldada, et ka täiskasvanu võib sama sõnaga viidata ühtaegu nii objektile kui ka helile, mida vastav objekt teeb: 
(7) (Mia vanuses 1;1.28)

EMA: kuidas teeb hobu?

EMA: ihahaa.

kommentaar: üks röökiv hälitsus Mialt

EMA: hobu, hobu, kallikalli, kallikalli jah.

kommentaar: Mia kallistab mänguhobust

MIA: mjää.

EMA: mjau on seal, seal on mjau.

kommentaar: kass on diivanil

(8) (Mia vanuses 1;2.15)

EMA: kes see on?

EMA: kala.

MIA: mulmul.

EMA: kala teeb mull-mull, jah.

Lapse varaste sõnade tähendus on lapsel esialgu reeglina laiem kui täiskasvanuil, väljendid katavad üldisemaid semiootilisi ja kognitiivseid tähistusalasid (Bloom 2001: 36, Laalo 1997: 187, Salasoo 2003: 154). Nii võib mõni sõna tähistada nii heli, tegevust kui ka objekti ennast. Semantilised piirid objektide, nende omaduste ja tegevuste vahel on lapse varaste sõnade puhul ähmased (vt nt Bloom 2001: 36). Seega võib väita, et helijäljenduseks ehk akustiliseks nähtuseks võib lastekeeles, ja nagu näidetest 7 ja 8 ilmneb, ka hoidjakeeles, olla ka objekt ise, mis selle akustilise nähtuse ehk heli tekitajaks on. Ja kui objekti ja näiteks selle objektiga teostava tegevuse kõige esilduvamaks tunnuseks on just heli, saabki sellest tunnusest helijäljenduslik sõna, mille selgem sõnaliigiline kuuluvus kujuneb välja sõnu liigitavate esmaste opositsioonide toel alles hiljem. Materjalist nähtub, et opositsioonide kujunemine algab semantilistel ja süntaktilistel tunnustel baseeruvast eristusest, morfoloogiline opositsioon eri sõnaliiki kuuluvate sõnade vahel kujuneb välja alles protomorfoloogilisel perioodil.

\section{Onomatopoeetilised sõnad muutuvad morfoloogiliselt keerukamaks nii laste- kui ka hoidjakeeles}

Paljud premorfoloogilise perioodi imitatiivid asenduvad protomorfoloogilisel perioodil tasahaaval vastavate konventsionaalsete sõnadega. Väide, et varased onomatopoeetilised sõnad asenduvad verbidega (Dressler jt 2002: 406) peab paika tugiverbikonstruktsioonide kohta. Kuid samas 
leidus materjalis ka hulk näiteid, mis demonstreerivad imitatiivide asendumist noomenitega. Nt ühendist teeb kop-kop saab lapsel vanuseks 1;5 verb kopsib, varasemast reduplikatiivist kiiga-kaaga vanuseks 1;5.20 verb kiigub ning kui vanuses 1;3 leidus Mia materjalis kassi kohta veel imitatiiv mjäu või njäu, siis vanuses 1;4 oli see asendunud konventsionaalse sõnaga kass. Samuti asendusid imitatiivid auh või auha ja prr sõnadega kutsu (vanuses $1 ; 5.20$ ) ja auto (vanuses 1;4.6). Üleminek ei olnud aga järsk: vanuses 1;5 on registreeritud küll verbivormid kopsib ja kiigub, kuid nendega paralleelselt leidus veel mõningaid tugiverbikonstruktsioone, nagu tegi kõmps-kõmps ja Mia teeb kuku.

Onomatopoeetiliste sõnade kuju muutub lapse vanemaks saades ka hoidjakeeles. Lapse vanuses 1;6 on hoidjakeelde lisandunud eelkõige onomatopoeetilise tüvega tuletatud verbe ja adverbe, mida vanuses $1 ; 2$ lindistatud materjalis veel ei esinenud: koputama, kopsima, haugub, kiigub, müraki, rögiseb ning sõnaliigiliselt interjektsioonide ja adverbide vahepeale jäävaid sõnu käuksti, hopsti, põmdi. Seega kohandab vanem enda keelekasutust lapse vanusele vastavaks, lisades onomatopoeetilistele tüvedele tasahaaval ka morfoloogilist informatsiooni.

\section{Kokkuvõtvat}

Onomatopoeetiliste sõnade, sh imitatiivide tähtsust lapse kõne arengu varasel perioodil ei tohiks alahinnata. Tegemist on sõnaliigiliselt ambivalentse, häälikuliselt kujult onomatopoeetilistele sõnadele iseloomulikult varieeruva, kergesti omandatava ning suuresti sotsiokultuurilistel rutiinsituatsioonidel põhineva sõnavarakihiga, millel on reduplikatsiooni kaudu oma roll kõnejada segmenteerimisel ja morfoloogia omandamisel. Onomatopoeetiliste sõnade hulka kuuluvad imitatiivid on lühikesed keeleüksused, mida ei tarvitse morfoloogiliselt muuta ning mida saab seega kasutada n-ö valmis kujul. See võimaldab lapsel olla keelekollektiivi liige ja suhelda juba siis, kui muutesüsteem pole veel omandatud.

Onomatopoeetiliste sõnade allikaks on hoidjakeel oma kindlate sotsiokultuuriliselt välja kujunenud tüüpsituatsioonidega, onomatopoeetiliste sõnade teatavates rutiinsituatsioonides kasutamise taga on suhtlusprotsessi lihtsustamise eesmärk. Lapse arenedes muutuvad suhtlussituatsioonid mitmekesisemaks, tüüpsituatsioonide ja sealt kaudu ka rutiinväljendite 
osakaal jääb vanema kõnes väiksemaks. Esialgsete imitatiivi sisaldavate tugiverbikonstruktsioonide asendumine sama leksikaalse sisuga tuletatud verbidega demonstreerib premorfoloogilise perioodi grammatikaväliste elementide taandumist ja üleminekut grammatika loomisele ehk protomorfoloogilisele perioodile. Seega annab onomatopoeetiliste sõnade sagedus ning muutumine hoidjakeeles tuge nii konstruktivistlikule kui ka sotsiopragmaatilisele keeleomandamiskäsitlusele: helijäljenduslikud sõnad moodustavad olulise osa väikese lapsega suhtleva vanema sõnavarast, on olulisel kohal vanema ja lapse igapäevastes rutiinsituatsioonides ja mängudes ning, mis siinkohal ehk kõige olulisem, muutuvad lapse vanemaks saades morfoloogiliselt keerukamaks.

Onomatopoeetiliste sõnade omandamise edasise analüüsi puhul tuleks tähelepanu pöörata ka neile aspektidele, mis siinsest käsitlusest välja jäid - foneetilistele ja prosoodilistele teguritele, mainitud sõnavarakihi ikoonilisusele, metonüümial baseeruvale sõnaloomele - ning arvestada ka seda, et saadud tulemused pakkusid ainult mõningaid vihjeid selle kohta, kuivõrd oluline võiks keeleomandamise seisukohast olla just hoidjakeele andmestik ja selle senisest põhjalikum analüüs.

\section{Kirjandus}

Argus, Reili 2004. Eesti keele käändesüsteemi omandamine: esimestest sõnadest miniparadigmadeni. - Emakeele Seltsi aastaraamat 49 (2003). Peatoim Mati Erelt, tegevtoim Maria-Maren Sepper. Tallinn, 23-48.

Bittner, Dagmar \& Dressler, Wolfgang Ullrich \& Kilani-Schoch, Marianne 2003. Development of verb inflection in first language acquisition. A cross-linguistic perspective. - Studies on Language Acquisition 21. Ed. by Peter Jordens. Berlin-New York: Mouton de Gruyter, VII-XXXIX.

Bloom, Paul 2001. How Children Learn the Meanings of Words. Massachusetts: A Bradford Book.

Clark, Eve V. 1993. The Lexicon in Acquisition. Cambridge University Press.

Coulmas, Florian 1979. On the sociolinguistic relevance of routine formulae. - Journal of Pragmatics 3, 239-266.

Dressler, Wolfgang Ullrich \& Kilani-Schoch, Marianne \& Klampfer, Sabine 2002. How does a child detect morphology? Evidence from production. - Trends in Linguistics. Studies and Monographs 151. Ed. by Walter Bisang, Hans Heinrich Hock, Werner Winter. Berlin-New York: Mouton de Gruyter, 391-425.

Dressler, Wolfgang Ullrich \& Marianne Kilani-Schoch, 2003. Are fillers as precursors of morphemes relevant for morphological theory? A case study from the acquisition 
of French. - Morphological Analysis in Comparison. Current Issues in Linguistic Theory. Amsterdam/Philadelphia: John Benjamins Publishing Company, 89-111.

Griffiths, Patrick 1992. Early vocabulary. - Language Acquisition: Studies in First Language Development. Ed. by Michael Garman. Cambridge University Press, 279-306.

Hausenberg, Anu-Reet 1981. Eesti ja soome onomatopoeetilis-deskriptiivsõnade käsitlusest tõlkesõnaraamatuis. - Sõnavara probleeme. Emakeele Seltsi aastaraamat 25 (1979). Tallinn, 33-38.

Jürvetson, Maria-Magdalena 2003. Havukka-ahon ajattelija romaanissa esintyvien infinitivus cum verbo colorativo konstruktioiden semantiikasta ja virontamisongelmista. - Lähivertailuja 13, 146-155.

Keelteatlas 2000. Toim Bernard Comrie, Stephen Matthews, Maria Polinsky. Tallinn: Koolibri.

Laalo, Klaus 1997. Alkukatsaus lapsenkielen esi- ja varhaismorfologiaan. - Virittäjä 3, 186-207.

Leskinen, Juha 2001. Suomalaiset, karjalaiset ja virolaiset korkeakouluopiskelijat imitatiivien käyttäjäinä ja tuntijoina. - Itameresuomalaista ekspressiivisanaston tutkimusta. Suomen kielen laitoksen julkaisuja 42. Jyväskylän yliopisto, 40-73.

Mikone, Eve 2002. Deskriptiiviset sanat: määritelmät, muoto ja merkitys. Suomalaisen Kirjallisuuden Seura. Helsinki.

Muischnek, Kadri 2004. Verbi ja noomeni püsiühendid eesti keeles. - Keel ja Kirjandus 8, 574-589.

Protassova, Ekaterina 1997. Transition from babbling to word structure. - Papers and Studies in Contrastive Linguistics 33, 153-158.

Savinainen-Makkonen, Tuula 1998. Ensisanojen kauden fonologiaa. Tapaustutkimus. Kielen ituja. Ajankohtaista lapsenkielen tutkimuksesta. Oulun yliopiston suomen ja saamen kielen laitoksen julkaisuja 10, 44-83.

Salasoo, Tiiu 2003. A Step in the search for an explanation of the acquisition of Estonian. - Languages in development. Ed. by Helle Metslang, Mart Rannut. Lincom Europa, 149-165.

Tomasello, Michael 2000. Perceiving intentions and learning words in the second year of life. - Language Acquisition and Conceptual Development. Ed. by Melissa Bowerman, Stephen E. Levinson. Cambridge University Press, 132-158.

Veldi, Enn 1997. Some typological characteristics of Estonian onomatopoetic formations. - Estonian: Typological Studies II. Tartu Ülikooli eesti keele õppetooli toimetised 8. Tartu, 220-238.

Veldi, Enn 1999. Lexicography of onomatopoetic words. - Estonian: Typological Studies III. Tartu Ülikooli eesti keele õppetooli toimetised 11. Tartu, 204-230.

Wescott, Roger Williams 1980. Sound and Sense. Linguistic Essays on Phonosemic Subjects. Lake Bluff: Jupiter Press.

Vihman, Marilyn May \& McCune, Lorraine 1994. When is a word a word? - Journal of Child Language Vol. 2, No. 1, 517-542.

Voeikova, Maria D. 1997. Early extragrammatical operations in the speech of a Russian child. - Studies in Pre- and Protomorphology. Ed. by Wolfgang U. Dressler. Austrian Academy of Sciences. Vienna, 37-44. 


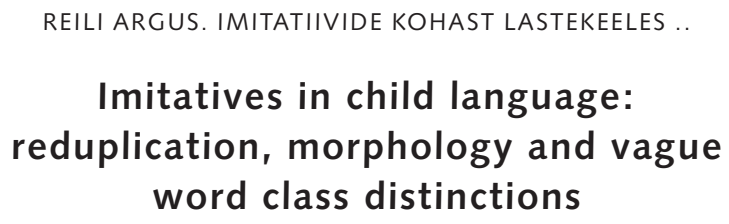

REILI ARGUS

The focus of the article is on the acquisition of the distinctly differentiated lexical layer of onomatopoetic words, imitatives. Both early onomatopoetic words in general and imitatives are in a period when there are no morphological characteristics in the language usage of a child and syntactic characteristics can not be spoken of due to the absence of multi-word expressions, belonging to ambivalent word class. Imitatives are short language units that need no morphological change and can therefore be used in a so-called readymade form. This enables a child to be a member of a language collective and communicate already in a pre-morphological period when the inflexion system has not yet been acquired. Imitatives are frequent and early in child language, caused mainly by their frequent use in the child directed speech and the propounding conditioned by the reduplicative structure. Already early imitatives are characterized by the regular alteration of sounds characteristic to onomatopoetic words. The usage of onomatopoetic words depends to a certain extent on sociocultural aspects: a certain language room has its characteristic words based on a number of traditional routine situations. As the child ages, in a protomorphological stage when the acquisition of morphology begins, the onomatopoetic words and imitatives become morphologically more complicated both in the usage of a child and the parent, also in the course of ageing there shall be less routine situations containing onomatopoetic words in conversations. It can be deduced that the more general purpose of a frequent use of onomatopoetic words and imitatives is the attempt of the one speaking with the child to simplify the process of their conversation. The usage of supportive verbal constructions and the later use of deduced verbs with a similar lexical content demonstrates especially clearly the speaking ability of a child to adapt his own language use according to his development. 
REILI ARGUS (1967) on lõpetanud Tartu Ülikooli eesti filoloogia erialal. Kaitses magistrikraadi Tallinna Pedagoogikaülikoolis 1998. aastal, töö käsitles süntaksi omandamist. Alates 2002. aastast töötab Tallinna Pedagoogikaülikooli eesti keele õppetoolis. Uurimisalaks on olnud esimese keele omandamine, paari viimase aasta jooksul on põhihuviks tõusnud kolmikute keeleline areng.

reili.argus@tpu.ee 